\title{
WILLIAM CROCKER'S PHOTOGRAPHIC COLLECTION AMONG THE CANELA OF CENTRAL BRAZIL
}

\author{
FABIOLA IUVARO ${ }^{1}$ \\ UNIVERSITY OF EAST-ANGLIA
}

\begin{abstract}
Dr. William Crocker began field research with the Canela (who live in Maranhão state, Brazil) in 1957 and continued to do so intermittently until 2011 - a total of more than fifty-five years. This time in the field exceeds that of any other long-term field research in Social Anthropology. As soon as he arrived among the Canela he began his intensive documentation of their life. Photography and film played a major part in his observation and his use of these media proved extremely innovative in ethnographic study. The material to be discussed in this paper can rightly be considered one of the most detailed and accurate sets of visual documents about Lowland South-American community life ever collected. Despite the importance of this collection and its potential to reveal material stories, it has remained largely unexamined and academically undervalued. My immediate aim in this paper is to re-examine Crocker's visual project in two different but related ways. The first is to look closely at his use of photography in the sense of drawing him out of his relative obscurity, and secondly, to focus my analysis on the circumstances under which the photographs were made, the theoretical ideas that informed them, and the methods employed in taking them in a degree of detail and in a manner that is, to the best of my knowledge, unprecedented. An interview I conducted with Dr. Crocker, today 92 years old, enriches our understanding of the archive collection. For those in the field, these important efforts touching on the archival impulse' of Crocker's research, illuminate various points of his work, his irrepressible desire to return to the original, a nostalgia for the recording of the place of absolute commencement.
\end{abstract}

KEYWORDS: photography; native Amerindian culture; archive.

RESUMO: $O d r$. William Crocker iniciou seu trabalho de campo com os Canela (habitantes do estado do Maranhão) em 1957, e continuou, de forma intermitente, até 2011, totalizando mais de 55 anos. Esse periodo de tempo é mais extenso do que o de qualquer outra pesquisa de campo de longo prazo na Antropologia Social. Assim que ele se estabeleceu entre os Canela, iniciou uma intensa documentação de suas vidas. Sua utização da fotografia e da cinematografia, uma parte essencial de sua observação, revelaram-se uma inovação no estudo

${ }^{1}$ Sainsbury Research Unit for the Arts of Africa, Oceania \& the Americas. University of East-Anglia, United Kindgom. PhD in Anthropology, expected December, 2017. Research project at the Department of Anthropology at the National Museum of Natural History, Smithsonian Institution, D.C. for forthcoming PhD Thesis. Dom Bosco Catholic University, UCDB, Campo Grande. Brazil. MPhil, Anthropology and Local Development, 2012. University of Arts and Humanities, Perugia, Italy. MPhil, Social Anthropology, 2009. University of Victoria, Manchester (Erasmus Programme), January 2008June 2008. Module: United Nations and the Anthropology of Development: Meeting the Millenium Goals in Latin America Countries. University of Arts and Humanities, Perugia, Italy. BA, Archaeology and Anthropology, 2007. E-mail: fabiola.iuvaro@gmail.com . 
etnográfico. O material que será discutido neste artigo pode ser considerado um dos mais detalhados e precisos conjuntos de documentação visual de um grupo das terras baixas da América do Sul já coletado. Apesar da importância dessa coleção, ela tem sido pouco examinada e pouco valorizada no âmbito acadêmico. O objetivo primordial deste artigo é reexaminar o projeto visual de Crocker por duas vias, diferentes mas relacionadas. A primeira é um exame atento de seu uso da fotografia, visando resgatá-lo de sua relativa obscuridade. A segunda é uma análise focada nas circustâncias de produção dessas fotografias, nas orientações teóricas sob as quais foram produzidas e nos métodos utilizados - considerando um grau de detalhamento que é, até onde se sabe, inédito. Um entrevista realizada com o dr. Crocker, hoje com 92 anos, enriquece nossa compreensão a respeito da coleção. Para aqueles em campo, estes esforços a respeito do "impulso arquivístico" da pesquisa de Crocker trazem à luz diversos aspectos de seu trabalho e de seu irreprimivel desejo de retorno ao original.

PALAVRAS-CHAVE: fotografia; cultura ameríndia; arquivo.

\section{Introduction}

My research begins with metal file drawers. A series of twenty of these were made to contain the more than fifty-five years of fieldwork among the Canela people undertaken by Dr. William Crocker, Curator for South American Ethnology in the Department of Anthropology of the National Museum of Natural History at the Smithsonian Institution in Washington D.C. ${ }^{2}$. At the center of the study is a section of his archive of images held at the Human Studies Film Archives and at the Smithsonian Institution in his office managed by Barbara Watanabe ${ }^{3}$.

My research is both an introduction to this remarkable collection and an invitation to reassess his collections of photographs, including those images that reside in the bottom drawers of his office. In particularly, the images I discuss were brought back from the field and filed in Crocker's collection at the Smithsonian. While working on his archive, I spent over a month looking at different visual sources; viewing

\footnotetext{
2 I particularly thank Dr. William Crocker for letting me interview him and sharing his immeasurable knowledge of the Canela with me. I would also like to thank him for providing stimulating and knowledgeable discussion and for his kind permission to reproduce the images from his collection here. I would like also to thank Barbara Watanabe (Museum specialist at the Smithsonian and Dr. Crocker's assistant) for opening the photo archive doors and providing guidance, and for her unwavering professional and personal support. Additional support, during my research was given to me by Mark White, video archivist.

${ }^{3}$ Museum specialist at the Smithsonian and Dr. Crocker's research assistant.
} 
and analyzing the photographs from his vast collection, and spending hours every day going through his data. Examining the contents of the photographic collection in his drawer showed me how the Canela visual archive was filed as 'anthropological' information, in which Crocker's important insights and experiences could be traced and externalized through the medium of photography.

Writing in the Foreword to Crocker's monograph The Eastern Timbira I: An Ethnographic Introduction, in the 1990s, Wagley commented that with this book, the Canela became one of the best known aboriginal societies of Lowland South America. I propose that if we add to this a detailed analysis of his remarkable archive of images about their life - the Canela will become one of the best known native cultures in the world.

I also suggest that the anthropologist systematic methodology and use of visual media as a way of 'recording the Canela way of life' can be defined as an unsurpassed individual undertaking in visual anthropology. There are very few anthropological field studies greater than Dr. Crocker's in duration and intensity. During his long fieldwork experience, he maintained almost daily contact with them from a distance even when he was not actually there. "This continuous monitoring of Canela society, added to his long term field research in residence, must be among the most intensive long term projects undertaken by any contemporary social anthropologist" (SPINDLER and SPINDLER, 1994, p. VIII). Firstly, one of the distinctive aspects of his research is that he devoted the whole of his professional life to studying only two closely related tribes: these being the Canela-Ramkokamekra and Apanyekra. The images discussed in this article focus on the Ramkokamekra-Canela living in Escalvado. Secondly, and significantly, once he arrived among the Canela, he began his intensive documentation of their life which continued intermittently for more than fifty-five years, and in which photography and film played a central role. His methodology consisted of a continuous tracking of Canela way of life mainly in the form of sequential photographs and slow motion images, using a newly developed power-drive on a Leica still camera. By so doing, he left us an impressive visual archive about the Canela encompassing virtually all aspects of their social and ceremonial life. 
In particularly, the anthropologists' visual project is massive and detailed (more than twenty thousand pictures and more than 146,000 feet of film footage), intermedia (verbal and visual, still motion picture, tape recording, plus a range of native artifacts) and collaborative work (during prolonged stays in the field with the Canela, Crocker asked cinematographer Steven Schecter to film between 1970 and 1979).

Today these data form one of the biggest collections of South American native people at the National Museum of Natural History, Smithsonian Institution. A discussion of all of these images is beyond the scope of this work. Suffice it is to say that one has only to look at the work of, for instance, Barbara Watanabe who has built up Crocker's collection in the Archive at the National History Museum at the Smithsonian, to gain some idea of the prodigious amount of data he generated during his stay among the group.

However, to understand his visual enterprise one must start by asking why Crocker took the photographs and film. The images did not constitute any part of his official publications, as inscribed, even as confirmation of a collection of information well recorded. Taking the photographs and filming was not even mentioned by the anthropologist, except very briefly in the Introduction to his monograph The Eastern Timbira l: An Ethnographic Introduction (1990). Yet conversely, to what has been published by him, if one looks at both the structure of the 'scientific' nature of his films and at the structure of his personal photographic albums, it is clear that his visual enterprise occupies an important aspect of his research. This was evident to me, sooner after my first visit to the Smithsonian in 2015 when I had the chance to look at his vast collection and his personal field notes.

While Crocker states "I consider my forte to have been not in my photography, which was merely part of Census Taking" (CROCKER, interview, 2016), from my discussion of a sample of his visual archive, it will become clear that one can extrapolate important information about the Canela subjects and contextualize important aspects of their life.

Despite his had somewhat uncertain intentions and relationship regarding dissemination of his photographs, my article aims to present an overview of his practices of photography among the group, which he mainly neglected. 
The images discussed contain some of the anthropologist's most poignant depictions of everyday Canela life, and as historical footage it contains images which are no longer 'capturable' by contemporary filmmakers. His collection represents a valuable historical 'artifact' in itself and on these grounds alone, one could argue it deserves its place in the anthropological literature.

The paper collects my data and examination of his archival material and initiates a conversation to connect different times, objects and memories. In my research, the 'archival impulse' as described by Foster (2004), helps to signify the urgent turn towards questioning and reconstruction of past events and philosophies. This research is a product of context, fieldwork experiences and the desire to piece together the fabric of imagination and storytelling that the archive of images reveals.

\section{William Crocker's research: a general overview}

Dr. William Crocker's research focused upon the Canela. He selected the Canela for study because Curt Nimuendajú had written his most detailed and comprehensive monograph about them. Crocker studied the references in the Handbook of South American Indians (STEWARD, 1946-1959), and found that 'The Eastern Timbira or Canela' (NIMUENDAJÚ, 1946) seemed to be the best subject on which to carry out a study. It is not insignificant that his earliest knowledge of the community was primarily visual. He went into the field with his mind filled with the images taken by Nimuendajú. Nimuendajú's monograph, based on research in the 1930s, provided Crocker with a baseline for a study in acculturation after 20 years. Thus, the anthropologist original motivation for studying the Canela was to evaluate cultural change. Nevertheless, the study does more than present two cross-sections in time of a society: between 1929-1936 (Nimuendajú) and 1957-1979 (Crocker). With the help of Nimuendajú's data, he wrote a diachronic history of the Canela from circa 1930 to the time of his fieldwork. Specific changes and directions of change in Canela society and culture were constantly described and discussed in his work. "For no other 
Lowland group do we have such detailed data on cultural change over a half century as we have from the observations of these two highly perceptive ethnographers" (WAGLEY, 1990, p. XX). In 1962, Crocker joined the Smithsonian Institution as a Curator for South American Ethnology in the department of Anthropology, in the Museum of Natural History. He devoted practically his whole professional life, in addition to his curatorial duties at the museum, to the study of this group. Significantly, during his extensive stay among the community, he assiduously prepared and used documentation, such as taking written diary notes, tape recording, a complete photographic ethnography (EDWARDS, 2001) and a series of films ${ }^{4}$.

\section{Photographs and film as histories}

The anthropologist photographs and film footage are a striking social and ethnological documentary of the changing visage of the Canela over a period of fifty-five years.

His visual project in the mid-twentieth century posits his photographic work as an important contribution to, and as a precursor of the kind of sociological analysis towards which visual anthropology was rapidly moving at the end of twentieth century (HOCKINGS, 1988). His fieldwork occurred during a time when there was a methodological shift away from studies and inventories of customs produced by early twentieth century evolutionary paradigms, towards studies based on long-term field research.

In American anthropology, longer-term fieldwork revealed the relationship between different elements of a society as it was at a particular point in time and 'opened richer veins of sociological data' (JACKNIS'S article on MEAD and BATESON, 1988) ${ }^{5}$.

\footnotetext{
${ }^{4}$ Funded by the American Museum of Natural History, he developed an extensive collection of photographic field data: still records (prints, Polaroids, and slides); films (16mm and Super-8) and material artifacts. In particular, at the National Human Studies Film Center (now Archives) of the Smithsonian Institution there are more then 146,000 feet of $16 \mathrm{~mm}$ film used to supplement field notes of the festivals, life cycle rites, sing-dancing, and sports. For my research I have examined: printed color and black and white slides (980), color prints (800), polaroid print (425), colored slides $(9,000-10,000)$ among original negative.

${ }^{5}$ For example, the overall aim of Mead and Bateson's visual project was to explore the relationship
} 
The detailed and permanent description in his personal and public documents created by Crocker's visual practice resulted from a "meeting of the often conflicting emotions of the anthropologist whose sense of rapid, cultural change ran alongside the documentation of continually traditional customary practices" (GEISMAR, 2006, p. 545). This methodological approach to 'lone experiential intensity', shifted the focus of his research and of the camera lens. Crocker's photographs, are not only reflections of this complex context, his images are what Geismar called 'emotional encapsulations' - "moments of communality and change, as well as documentation of more continuous traditions, illuminated perfectly by the presence of the ethnographer's shadow alongside the ephemeral visual documentation he is recording for posterity" (GEISMAR, 2006, p. 546).

He was not the first anthropologist to use the camera in the field, but his work was significant for its use and valorization of photography in anthropology as a primary recording device, and not merely as illustration (MEAD and BATESON, 1942).

An interesting point is that he was an active proponent of the National Anthropological Archive at the Smithsonian Institution in the mid-1970s ${ }^{6}$. He was listed on the Advisory Committee and as a member of the Anthropological Film Research Institute along with Margaret Mead and others.

Crocker and Mead's anthropological perspective was predicated upon the race to record unique cultural material, subject to inevitable change (JACKNIS, 1988). Crocker points out, "I was not used to film. Still shots, yes. After Nimuendajú, I was the main ethnographer. The Canela were losing their material culture, so I had to record it before it was gone. This is not why I was there, but it was a responsibility" (CROCKER, interview, 2016).

The anthropologist clearly felt this responsibility to record with his camera the manifestation of the unique way of life of the Canela. He

between parents-child interactions.

${ }^{6}$ The Human Studies Film Archives (HSFA) is devoted to preserving, documenting, and providing access to anthropological moving image materials. The Archives officially began its mission in 1975 when, as the National Anthropological Film Center, it initiated a program that both created and collected films and photographs of anthropological research interest. The archives promote the importance of moving image materials as an integral part of the anthropological record related to documentation and research. 
achieved this by direct observation and photography, stating: "Cameras and other recording devices are so valuable because they can provide us with material that can be repeatedly reanalyzed with finer tools and developing theories" (CROCKER, interview, 2016).

More importantly, by means of visual media (photographs and film), Crocker ended up highlighting what he has called an expressive culture - the life cycle and daily cycle of activities, recreation, and material culture.

Despite this landmark status, his visual achievement in my opinion has been subjected to surprisingly little consideration. In spite of the importance of its archive images and their potential to reveal material stories, they had existed quietly in the Smithsonian.

I shall be arguing that in comparison with Mead and Bateson's visual enterprise, they have received considerable more attention since 1988, because of Jacknis's ground-breaking article (JACKNIS, 1988; HENLEY, 2013). While with the signal exception of brief commentaries by Wagley in the 1990s, Crocker's archive of images has been the subject of remarkably little analysis in the anthropological literature. Wagley noted how viewed as a study in visual field method alone, the anthropologist's work is an important contribution to visual and social anthropology, not only for the importance of its theoretical substance. Apart from Wagley, there was only an online publication in 1998 made by the Smithsonian Human Studies Film Archives, about the one-hour film called "Mending ways: the Canela indians of Brazil", which Crocker made with film-maker Steve Schecter7, broadcast by the Discovery Channel, 29 times as of September 2002, to bring the story of the Canela to a wider audience.

I hope to demonstrate that although, in its time his visual project was greeted with some puzzlement, even by Crocker himself, perhaps because he had a somewhat uncertain relationship with disseminating his archive and collection of images by the conclusion of his longfieldwork among the group, his work deserves valuable and historical assessment.

\footnotetext{
7 The video - edited by Crocker and with the help of Steve Schechter, filmaker and Crocker's collaborator - has been culled from over 90 hours of film and video among the group. The National Geographic Society bought the international cable rights and the Discovery Channel bought the domestic rights.
} 


\section{The Overlooked}

The fact that Crocker missed regular teaching at university, could have blunted the recognition his work deserved. He was unlike Mead, for example, who spread her views on visual anthropology through teaching at the Columbia University and in several programmatic articles (JACKNIS, 1988, p. 172). Crocker was less inclined to propagandize for the use of photography in the anthropological forum. Although George and Louise Spindler added that - "even if he has been away from the academic forum, he appreciates the opportunity for intensive and longterm research his career at the Smithsonian has provided, where he continued to use film and photographs as 'field records' in his research" (SPINDLER and SPINDLER, 1994, p. XX). Yet in disseminating the record, Crocker appears to participate in this marginalizing process himself. In answering my questions about his arrangements for publishing the fieldwork photographs, he says that he did not intended to actually turn his visual reports into an album for publication (CROCKER, interview, 2016). On the other hand, Crocker clearly valued his archived visual collection as an important part of his scientific endeavor and perhaps, he is conscious of how much he had left undone. He advocates:

I always intended that my voluminous field materials would one day be accessible (as they now are) for future researchers to examine, to form the basis for alternative interpretation (CROCKER, interview, 2015).

Taken together as a corpus of images, his work represents an interesting form of 'a photographic ethnography' structured by a 'real narrative' (EDWARDS, 2001), where the quality of the images is very high. That is to say that he produced a chronological documentation of Canela life, where the corpus of images involves a higher degree of spontaneity on the part of the subjects, and more generally, a greater correspondence to their everyday reality. This degree of reality was reached by his systematic methodology based upon the use of visual media among the community, from the beginning of his career and by his intimate engagement with the community. 
Henley (2013) recently posits how while for predecessors such as Alfred Haddon, Baldwin Spencer or Franz Boas, filmmaking and photography were merely one peripheral strategy, it was absolutely central to Mead and Bateson's fieldwork methodology. I would add that it was a central resource for Crocker too. I suggest that his visual work can be compared with what Henley (2013) said of Mead's visual enterprise, when he posits how Mead's visual work anticipated the development of the "time-based narratives that characterized ethnographic visual work in the later post-war period8" (HENLEY, 2013, p. 101).

However, I shall discuss important stylistic features which mark Mead and Crocker's visual enterprises as very different from each other.

Henley points out some contradictions between theory and practice in Mead's works, principally her detached observation and disengagement - an integral feature of Mead's method of taking her field notes, where the subjects were often shot at "an oblique angle poorly framed and from a distant vantage point" (HENLEY, 2013, p. 88). It is my understanding of Crocker's work that he was, on the contrary, intimately engaged with the Canela, using the camera so as to be directly involved in the action, right in front of his subject, moving around shooting from a variety of angles. This is probably explained by the fact that he had a much closer relationship with the 'subjects' having worked with them for several years. Perhaps, Henley noted how Bateson himself expressed concerns over Mead's visual practices and in a celebrated exchange with her, recorded in 1976, completely rejected Mead's idea that when used for ethnographic purposes, "the camera should be placed in a single static position, on a tripod, and left there to take shots for as long as technically possible, without any variation in framing or angle of view9" (HENLEY, 2013, p. 101). Bateson according to Henley posits that, "if the filmed material is to have any meaning, it should be shot in a 'creative manner', with the camera person moving

\footnotetext{
${ }^{8}$ Henley refers to Trance and Dance, the film most remembered of Mead.

${ }^{9}$ Mead in fact according to Henley (2013) was alarmed that Bateson should repudiate their earlier work in "such a radical fashion and advocate instead 'artistic' practices' that could reduce the scientific potential of her material record" (HENLEY, 2013, p. 101). Crocker, differently to Mead, paid attention to the quality of the images. Crocker's images are of an extraordinary quality, beautifully framed and engaged.
} 
around shooting material in accordance with what he or she thinks relevant at that particular moment" (HENLEY, 2013, p. 102). Interestingly, if we consider Henley's analysis of Mead's work as a reference to compare with my understanding of Crocker's work - his visual enterprise, can be defined as the best example of the combination between what Bateson called 'a creative treatment 'of the camera, and the 'use of a structural narrative' present in contemporary ethnographic visual works.

\section{Crocker's drawer at the Smithsonian}

The aim of this section is to consider the general circumstances under which Crocker's archive of images about the Canela was made, outlining the structure of his anthropological record in order to explore what caused the anthropologist to record photographically and film the Canela way of life.

His collection is characterized by a very specific organization and technical method which I suggest is practical and useful to examine systematically.

For the most part, the series of images (photographs) were organized chronologically and by year, into sections with ethnographic annotation appearing alongside an illustration of the event, producing new images to enter the museum archives "with the explicit intention of facilitating the possibility of future activation" (CROCKER, interview, 2015). Additionally, in his field notebook he devised a system of abbreviations indicating the state of the subjects, namely for example kinship relationships, married status, and added notions of the publishable quality of the image. Crocker came up with a system of "running field notes," essentially a chronological narrative of observations (MEAD, 1942; JACKNIS, 1988). The running field notes were supplemented by a daily diary in which he recorded all the different kinds of activities in the field: photography, events observed, births and deaths, illnesses, letters and visits, ceremonial life etc. He added contextual information which included the day of observation (and of write-up), a summary title of the action, a complete list of 
people present, the kind of photography used (moving or still, with identifying numbers), and the general cultural themes or behaviors exhibited or the ongoing social action. His personal captions indicate how much the photographs in his drawer have been re-contextualizedpersonal names, Canela language, notes on photographic technique, and ethnographic detail. In this way, his work offered a new model for integrating images and text. Crocker clearly drew upon his experiences as a museum curator to direct the archive collection of Canela ethnographic facts, encouraging detailed account of social practices, sufficiently random so as to benefit professionals concerned with advancing broad theories on the development of the community studies. His archival visual collection may be seen as a potent meeting point for contemporary anthropological images and ideas.

\section{Photographing the field}

For the purpose of this work, Crocker's photographs and images elicit a composite view of Canela life, between 1957 to 1970, culminating in the formation of his drawer within his Photographic Collection at the Smithsonian 10 .

The anthropologist's camera focused on the everyday in a way that reflected his interest in subsistence activities: farming-oriented topics, hunting, and food collecting; but also on sharing activities, namely, food distribution and child care activities.

The prioritization of this footage, or "field notes," were also used to film the village houses and the village center where all the Canela activities took place.

\footnotetext{
${ }^{10}$ The images considered for this paper are from 1950s to the 1970s. Although, I have to remember that Crocker continued to systematically and photographically record the Canela way of life until up more recently 1999. While the "last Canela photos were taken by William Fisher in 2011" (BARBARA WATANABE, interview, 2016).
} 
Figure 1. A sequence of Crocker's photographs showing Canela village in the 1960s.

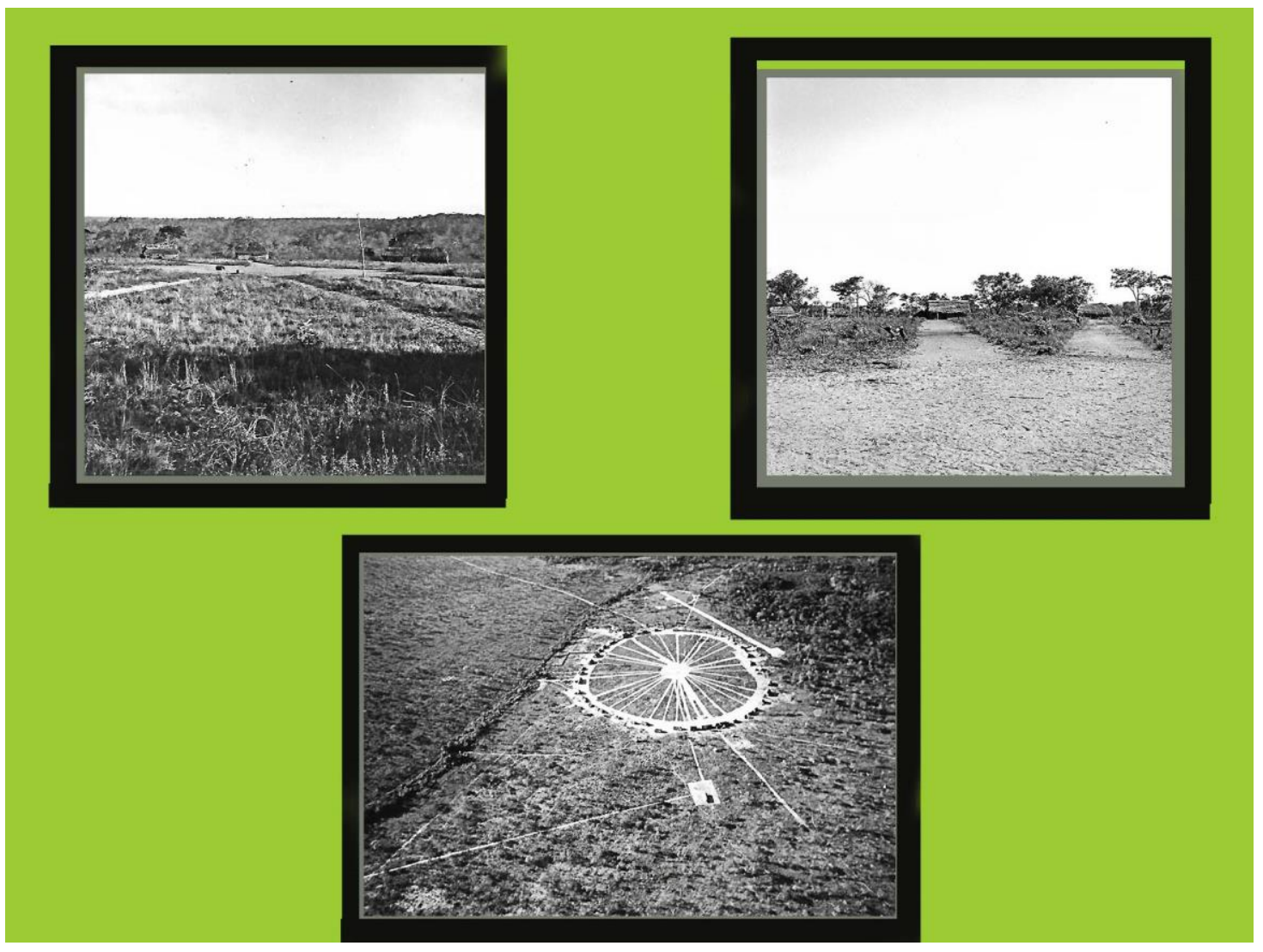

From the very beginning of my analysis, I realized how invaluable the historical records that Crocker left to us were'11. Whilst it was Crocker's intention to help capture, document, and even salvage traditional practice in the face of great cultural change, his images also provide us with his attempt to communicate intangible aspects of their culture. This is consistent with Bateson and Mead's theory:

adding photographs to our analysis we are attempting a new method of stating the intangible relationship

11 Overall, all the photographs showed are a sample of the Crocker's systematic methodology in recording Canela life, each visit for a period of more than fifty-five years, that is incredibly unique. The images in the sections come mainly from Crocker's project called Census taking Series, where he recorded photographically qualitative and quantitative information about the Canela way of life ranging from the size of the population each year, to incredibly detailed aspects. For example, he portrait in detail each year of his fieldwork the way they ate, to what was inside their houses, to how people were preparing communal meals. Interestingly, some of these data were incorporated into the first official census in 1970s in Brazil, as conducted for the Brazilian equivalent of the Census Bureau, the IBGE, the government's conducted first ever research and official data about their indigenous population. (Important data from this project were analysed by Greene and Crocker, 1994.) 
among different types of cultural behavior by placing side by side mutually relevant photographs. By the use of photographs, the wholeness of each piece of behavior can be traced by placing the series of photographs on the same page (BATESON and MEAD, 1942 , p. 56).

Interestingly, in 1957, he wrote how he had wanted to justify a qualitative approach to appraising anthropological data since his early graduate school days in Stanford University.

When I first arrived in the Canela village in 1957, my impressions were of individuals who showed great selfrespect and pride, and believed in their traditions. I was impressed by the dignity and proud bearing of older people (CROCKER, 1990, p. 27).

A passage from his fieldwork diary reveals how visual and aural research practices were integrated in his participation with the community. He tells us how when he arrived among the Canela in August 1957, the reputations and names of Curt Nimuendajú and Olimpio Martins Cruz encouraged their acceptance of him. According to Crocker, the Canela wished that he was Nimuendajú 's nephew because that would have meant from their view of kinship that he was in his rightful place. Because Nimuendajú had been with the Canela as an ethnologist for 14 months from 1929 to 1936, Crocker was not such a novelty and his acceptance into the community was achieved within a week (CROCKER, 1990, p. 26). Crocker reports how well he got along with the Canela, how they adopted him, gave him a family via an adopted sister, and bestowed on him a special name which afforded him certain rights and honorary privileges. He reveals how "being adopted into a Canela family, was the most successful and important event for my fieldwork among the group. As one of the family, I was able to participate in their personal and ceremonial life" (CROCKER, interview, 2015).

The anthropologist creates an intense and familiar relationship with the group, and because of that he was able to shoot some of the most comprehensive photography ever conducted on the Canela and of their most important ceremonies. 
When my favorite niece Tekura died of tuberculosis in my Canela sister's house, I attended her funeral proceedings without pad and pencil and also without a camera. During the middle of the rite, however, the understanding older Kaapeltuk came over and asked why notes were not being taken and pictures snapped. Stunned, I came back with my equipment and photographed it, including views above and close to the cadaver, while my female kin were wailing (CROCKER, 1990 , p. 28). (Figures 2-3).

Figure 2. A sequence of photographs showing Tekura's funeral. Crocker's niece in his Canela sister's house.

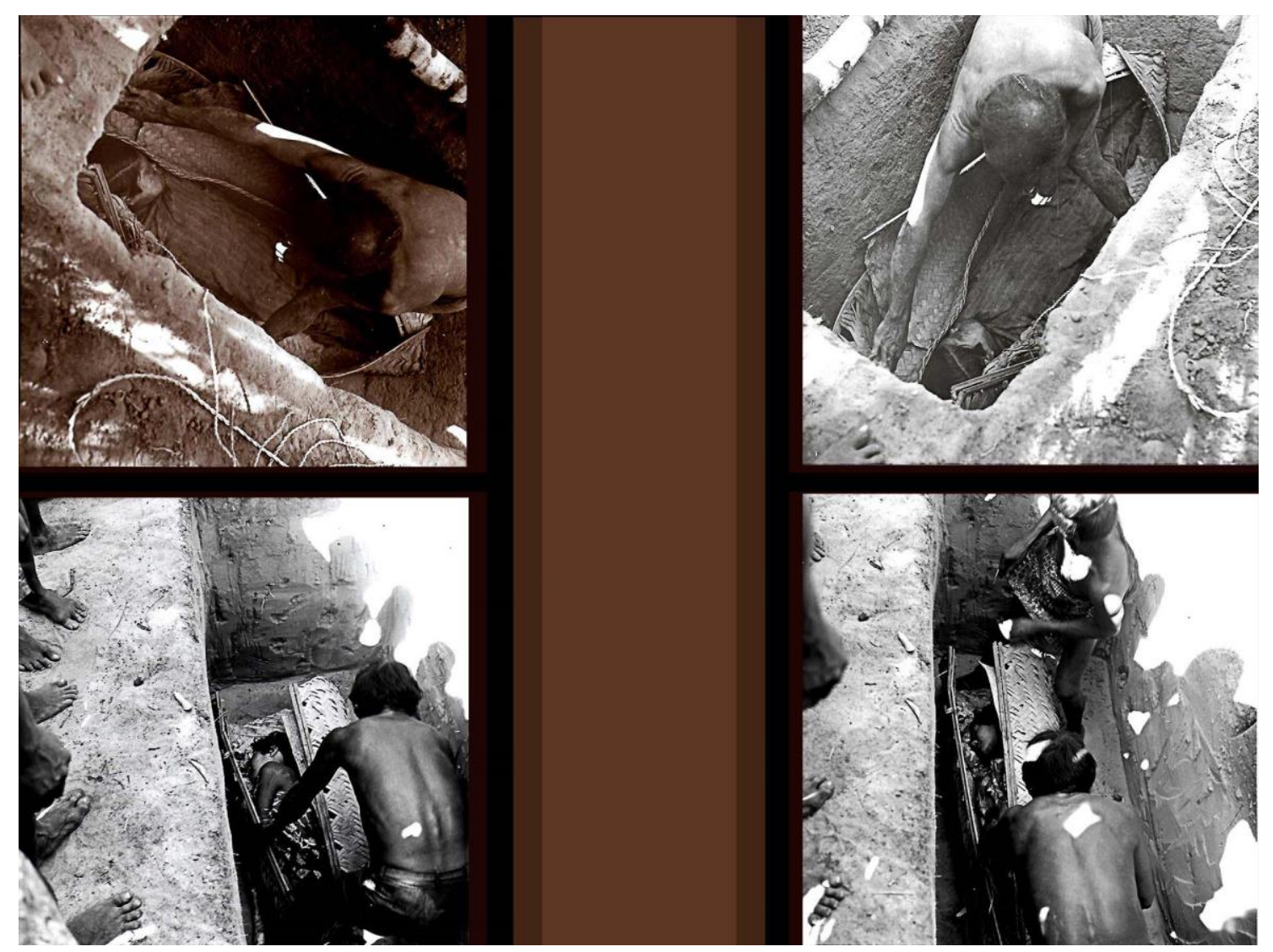


Figure 3. A sequence of photographs showing Tekura's funeral. Crocker's niece in his Canela sister's house.

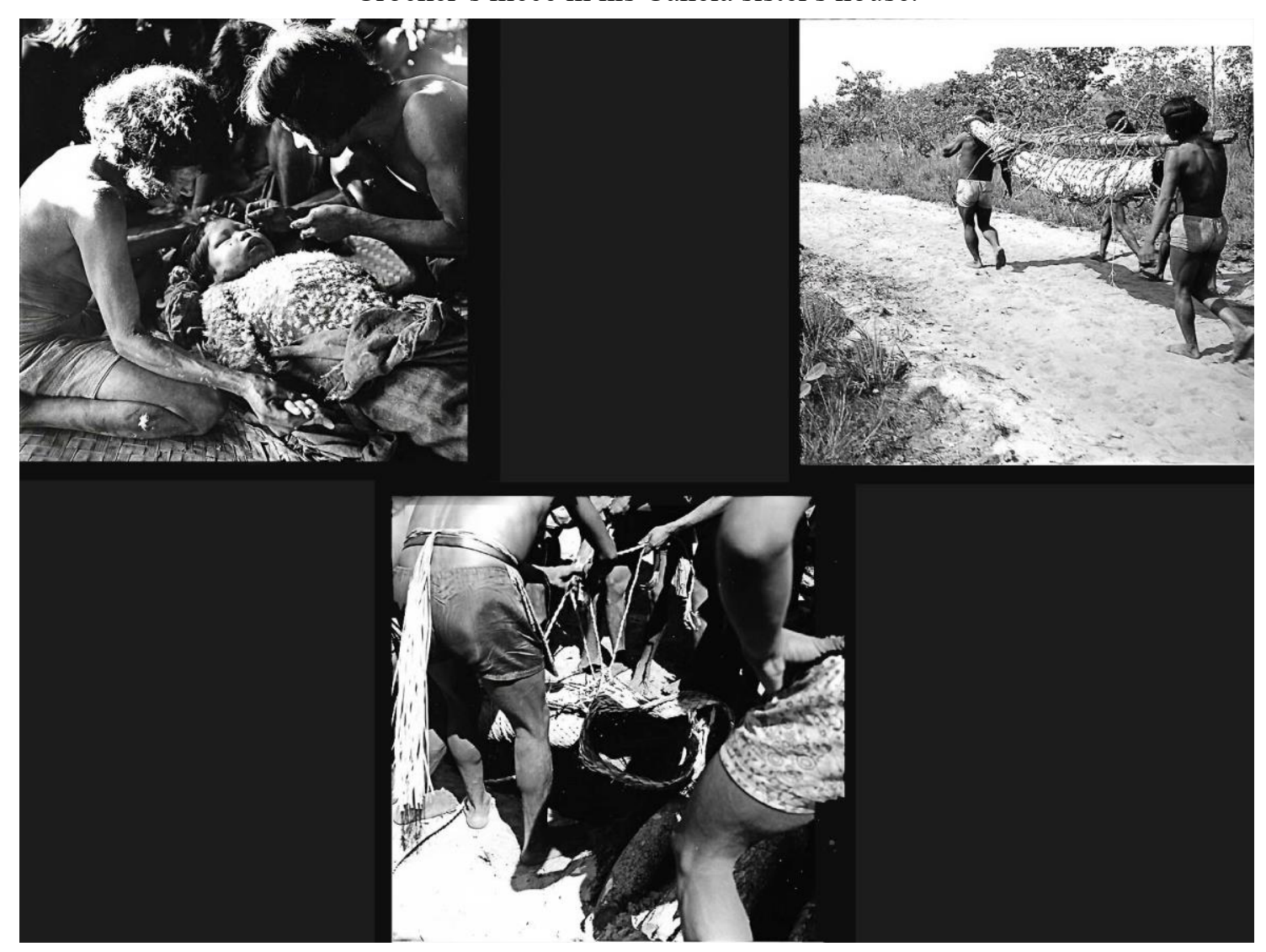

The anthropologist, from that occasion onward, became aware that his role as an ethnographer, as well as a tribe member, was firmly established. The tribe's recognition of his ethnologist status made it possible for him to record their festivals and other aspects of their life more intensively. This, he admitted, was the greatest achievement of his early fieldwork. He reports that one of the elders of the community encouraged him to visit him at any time for instruction and was unconcerned about payment. He understood that Crocker wanted to dig deeper than Nimuendajú had and felt a responsibility to pass on his knowledge of their heritage and traditional customs to a serious student of the culture (CROCKER, 1990, p. 43).

It's also clear from his archive that he continued to use his photographs after his return from the field. "I am still only digging through a shadow of an existence, which consists of a never ending chain of inspiration" (CROCKER, interview, 2015). One soon realizes that his collection of photographs was more than 'just a method of factual 
elicitation' (GEISMAR, 2006, p. 546) but more a direct emotional link between Crocker and the Canela, a way of thinking and knowing that could draw him away from mental challenges and lead him back to writing. He clearly felt that his visual productivity, in particular his film footage and photographs, was one of his most important fieldwork achievements. Moreover, the design and implementation of his method to depict systematically Canela way of life, left us qualitative material which can be used for a variety of investigative purposes.

\section{Viewing Crocker's images today}

His photography collection suggests two possible but related directions for investigation. Firstly, it reveals an unconscious desire and interest in such a photographic record in order to describe the histories of the subjects, the Canela themselves. There is a 'non-interventionist quality' (EDWARDS, 2001), and very few photographs are frankly set up with the exceptions of children's games, or in a very different context, 'physical anthropology' (EDWARDS, 2001). The anthropologist posits how he was just following them and trying to describe everything that was happening before his eyes. A number of procedures were used by him to lessen the intrusion of his camera into their natural behavior. "Limiting the vast quantity of shots taken and footage exposed during the day for example. I Just took them as a matter of routine, wearing or carrying the cameras day in and day out, so that the photographer himself ceased to be camera conscious" (CROCKER, interview, 2015). From my discussion of a sample of his visual archive, it will become clear that one can extrapolate important information on the Canela and contextualize important aspects of their life.

Secondly, Crocker's own photographs demonstrate 'a nascent methodological and observational model' (PINNEY, 1992) that can be perceived both in his informal comments in his monograph and through a close reading of the images. John Collier's text on visual anthropology commented that photography in the history of anthropology declined in importance: 
Usually an anthropologist takes a photograph to illustrate a finding that he has already decided is significant... he waits until whatever it is happens, then points his camera at it. His camera then is incidental to his research activity and comes into use late in the fieldwork period. He uses the camera not as a research technique, but as highly selective confirmation that certain things are so, or as a very selective sample of reality (COLLIER, 1967, p. X).

But it should be noted that the anthropologist was quite sensitive to charges of subjectivity; he admitted:

I tried to shoot what happened normally and spontaneously. I treated the cameras in the field as recording instruments, not as devices for illustrating my theses (CROCKER, interview, 2015).

Thus, the collection reveals an interest in familiar relationships and especially in ceremonialism, but within this trying to be as inclusive and random as possible.

\section{The Census Series Project}

Firstly, flipping through the card in his drawer, I was interested and surprised by the first prints one encounters, called Vital Stats ${ }^{12}$ which are of original films, metal stamps for records, stock shots, photographic negatives, and other original material, showing the physical environment within which Crocker's fieldwork took place, (Figures 1-4), followed by the portraits of all the people living in the village (Figure 5). This project gives way to a series of photographs catalogued as Census Series. Crocker states:

The Census Series [project] was the best way to record Canela culture before it was gone. It was the best way to do it, and beyond words, the camera was the best way. Then, others could see later and interpret (CROCKER, interview, 2016).

\footnotetext{
12 According to Barbara Watanabe, museum specialist at the Smithsonian and Dr. Crocker's research assistant, the "Vital Stats it is short for statistics" (BARBARA WATANABE, interview, 2016).
} 
Figure 4. A series of photographs showing Crocker systematic methodology of recording techniques.

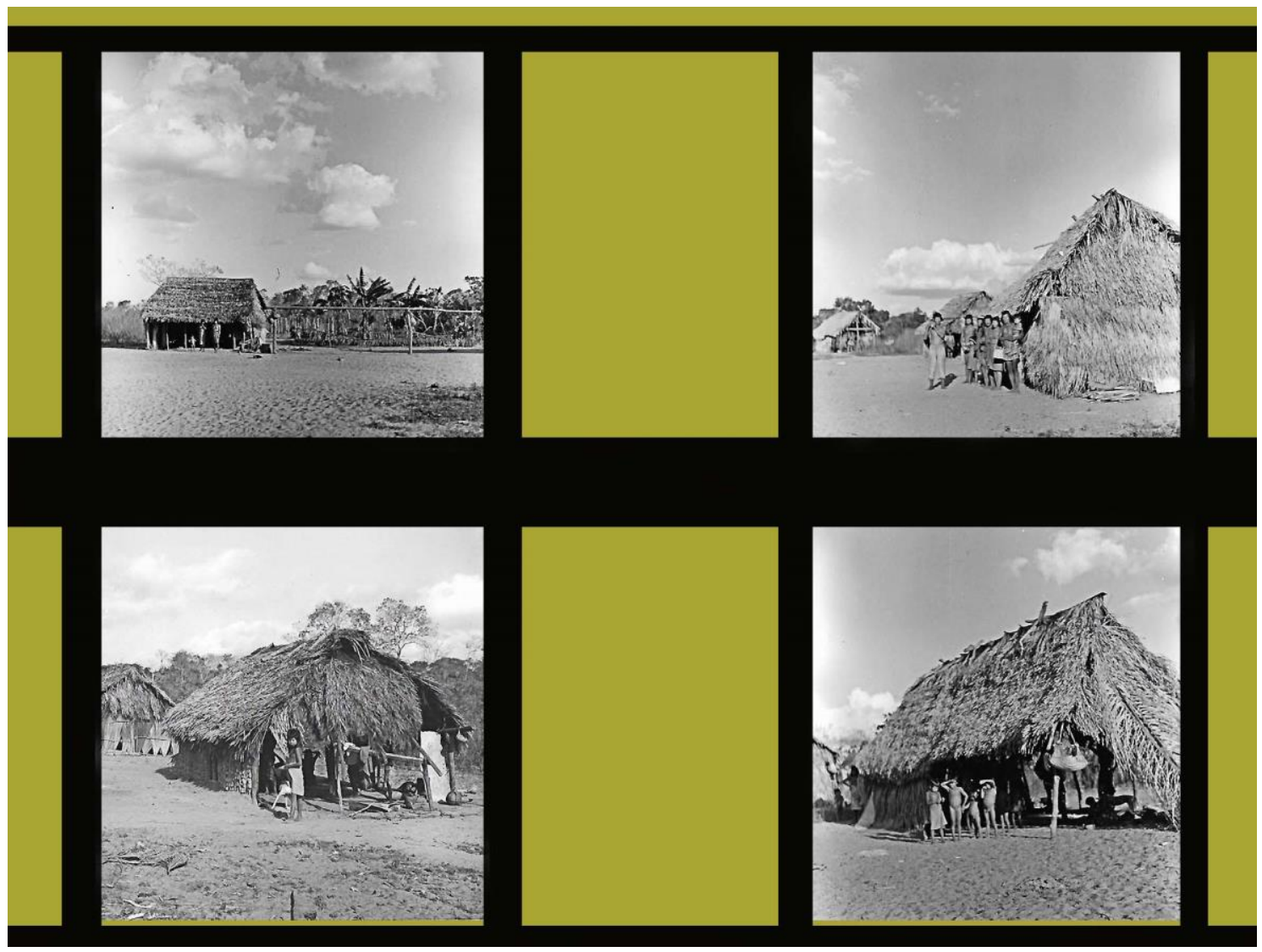

For example, in order to record how many people lived in each house, he was not happy to just shoot the people themselves, but also gave us the context in which he shot them. From the images we can see how, in order to record quantitative information about the size of the population each year, he started to shoot from a distance so as to provide a wider visual perspective of the overall scene. Finally, he goes in close with his camera, as will be seen in the next figure (5) below, where he actually photographs each member of the Canela household. Interestingly, in the provision of wider context mentioned, in the last image of the sequence, we see the family on the right side at the bottom, standing outside their house, with their hands up to their faces, the sign of seeing someone in the distance, most likely with the sun in their eyes. This is probably a clear example of how the family were outside awaiting the visit of the anthropologist.

Inscribed in these is the history of the Canela's settlement pattern and land use, their spatial arrangements and the number of the population (I considered only images from 1957 until the 1970s), representing the minutiae of history and Malinowski's 'imponderabilia of actual life' (1922). 
Figure 5. A series of photographs showing the way in which Crocker framed his images, giving us clues to the experiences he had producing them; for example, their smile while posing, show the anthropologist's familiarity with the Canela and how the community was attached to him.

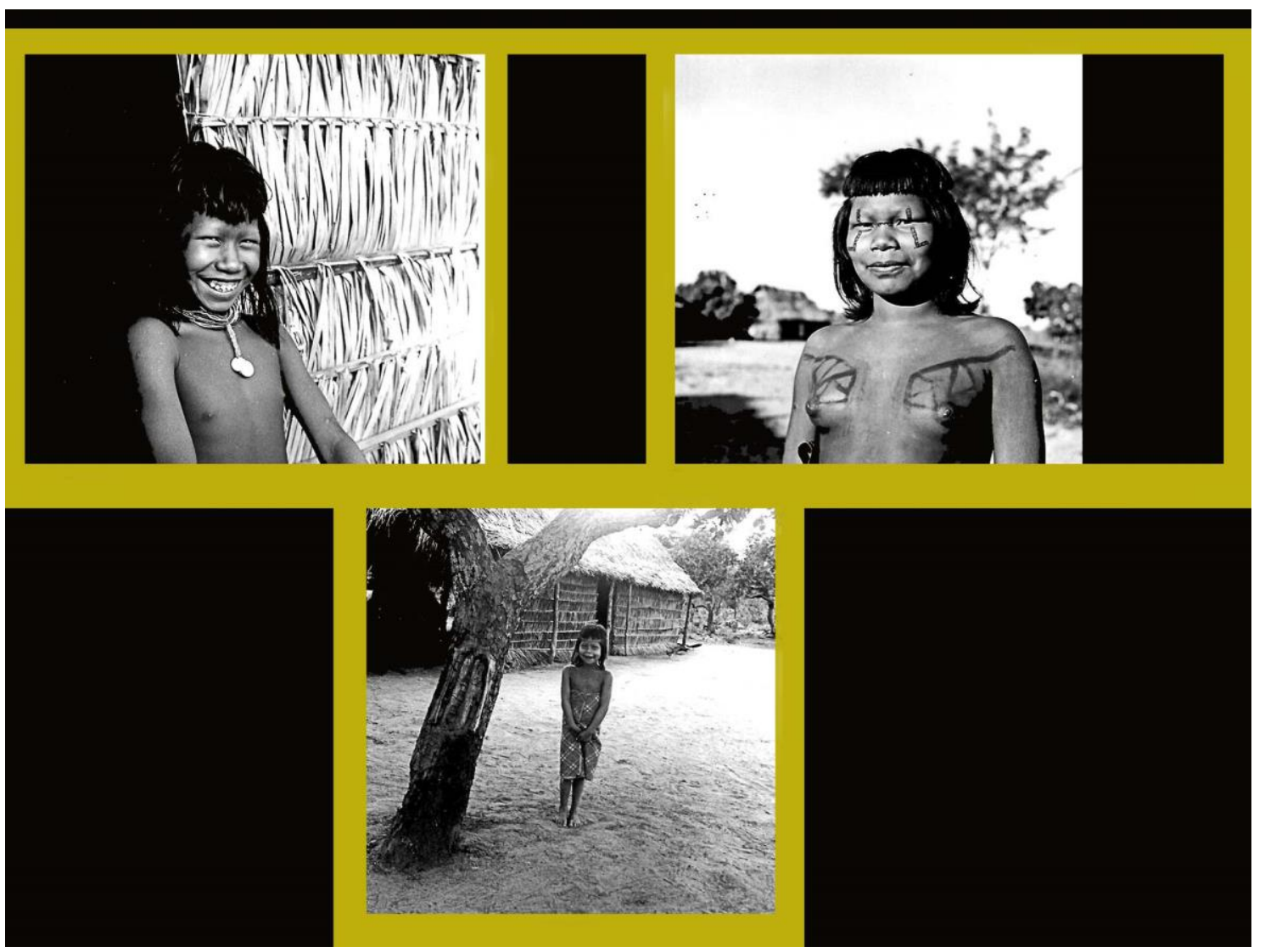

An ongoing view of the Canela cyclically over time was thus perpetuated. The photographs, in particular, are arranged conventionally. The viewer is led through a narrative of place and then through 'functionalist ethnographic categories' (EDWARDS, 2001, p. 34).

For example, Crocker took care to photograph both the interior and the exterior of every house in the Escalvado village circle on every visit, as well as two pictures of the whole family. Each family received one Polaroid print while the other was kept for the record. On his return he would send each family a larger print as well as any other relevant pictures (CROCKER, 1990, p. 34).

But as Edwards (2001) observes, even the "forensic or evidential level in photographs, implies an enmeshing of the image with other systems" (EDWARDS, 2001, p. 90). 
Figure 6. A series of photographs showing the interior and the exterior of every house in the Escalvado village circle on every Crocker's visit.

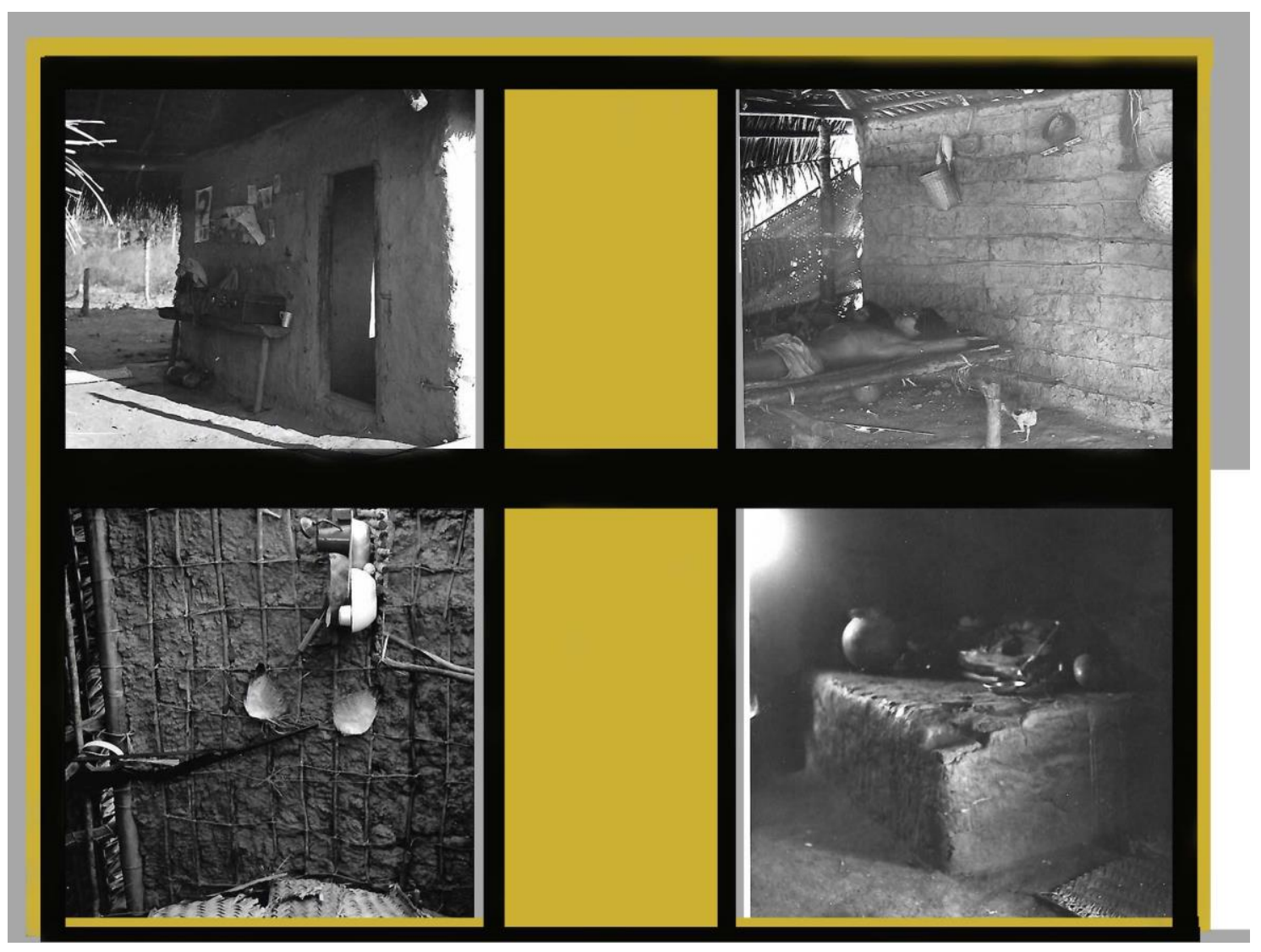

Overall, the 'Census Series' reveals Crocker's ideas about Canela community life, but it involves much more than just "counting heads" (CROCKER, interview, 2016). While this photographic collection of quantitative and physical information seems at first glance to fit into the contemporary paradigm of social anthropology, the way in which he framed his images (giving us clues to the experiences he had producing them) may be seen to as his indices of Canela sociality. Interestingly, he notes:

In the late 1950s, I spent much of the noon period running errands for myself, which was usually exhausting but exposed me to many people and to what was going on. When I could break away from errands, my Canela sister or brother's wife gave me lunch, which was the same as breakfast or dinner: manioc flour with beans and grass tea, rice with chicken bits and oranges, or meat pie (manioc and pork) with bananas and brown sugar (rapadura) tea 
(CROCKER, 1990, p. 26).

While Crocker was pursuing the task of recording quantitative information about the Canela village in the Census Series project, his photographs were used to frequently reference activities going on around him and the quotation shows his familiarity with his subjects, and his evident attachment to the local community.

Figure 7. A series of photographs showing Canela daily activities.

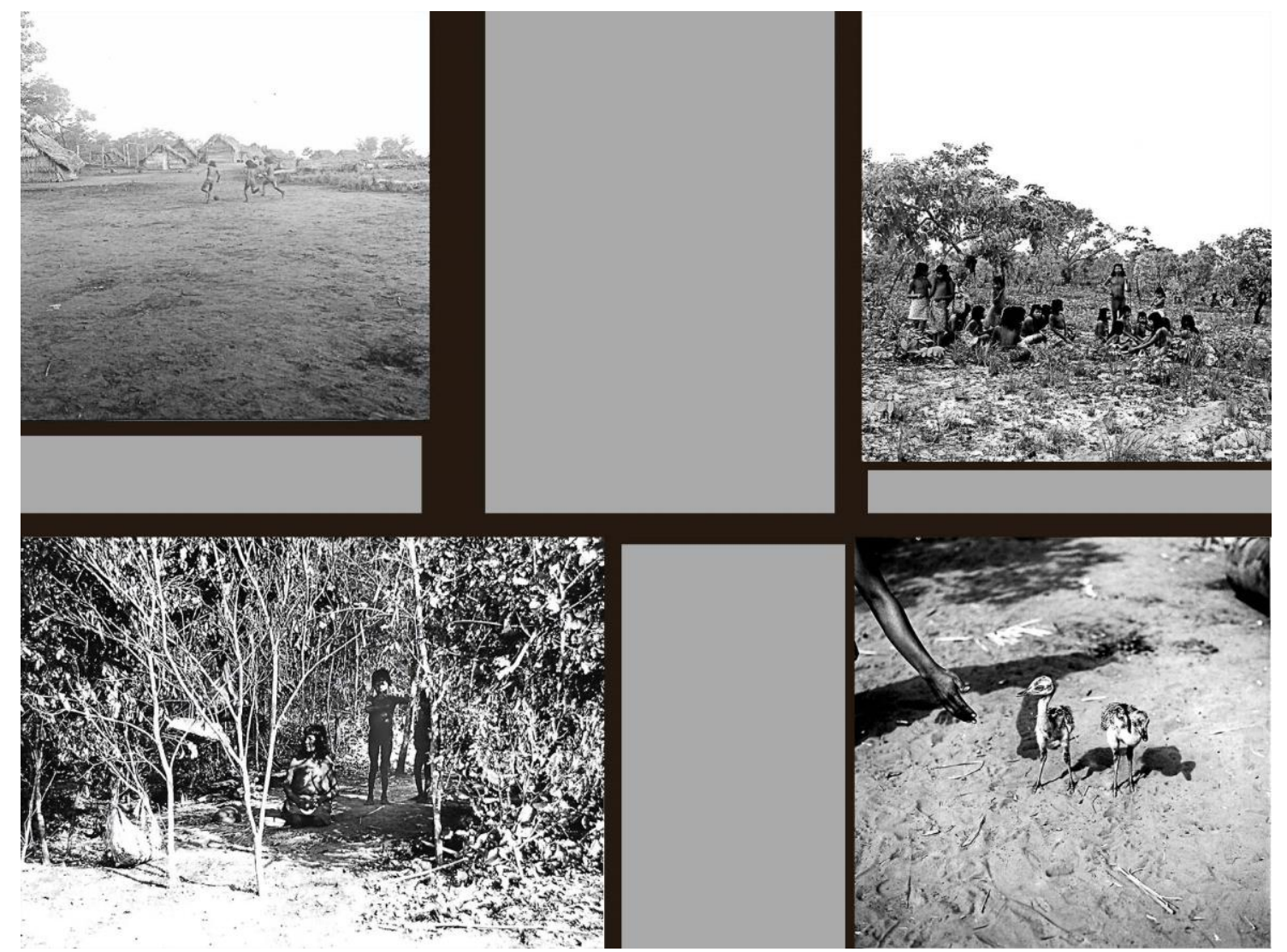


Figure 8. A series of Canela's daily life activities.

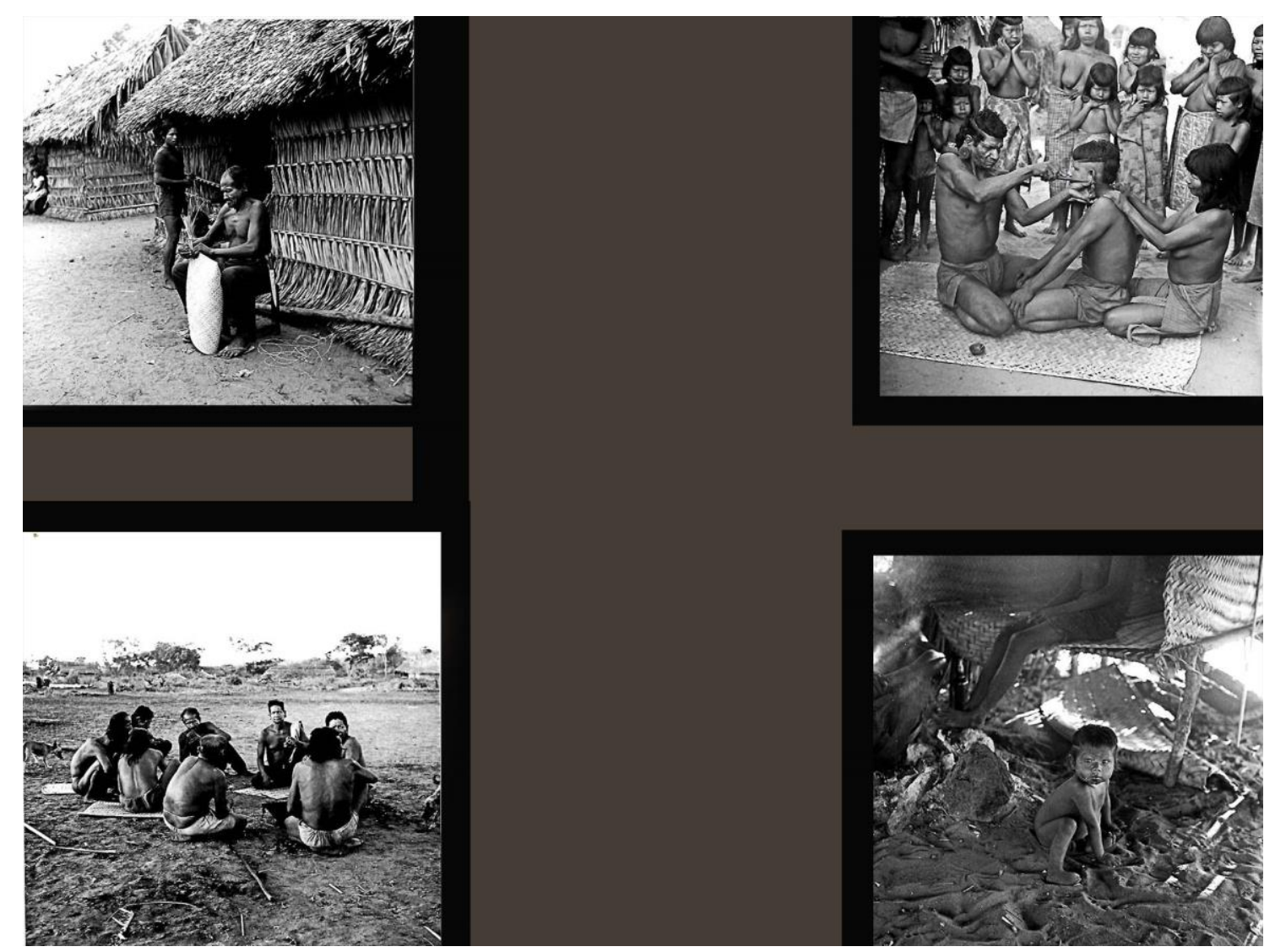

This is especially pertinent in relation to his comments in his monograph The Eastern Timbira I: An Ethnographic Introduction (1990), about how he finds ample opportunity to casually observe what people were doing by simply sitting on a mat or chair and 'eating three meals a day' in the Canela's residences. "By being inactive but eating and observing, I was one of the many fixtures of such rooms" (CROCKER, 1990 , p. 26). Thanks to this familiarity with the group, he could watch what was happening in other large rooms; for example, he took notes on the spot, or spoke into a microphone in English without disturbing the family interaction. He would often travel with whole families to farms or other villages. These trips were slow, lasting as long as three days, and he reported how the women and children took a long time preparing for moving and then only walked slowly. He had time to observe minute details about the traveling and the group; he wrote or took simple notes and produced still shots or motion pictures, for later elaboration (CROCKER, 1990, p. 35). 
Importantly, one can argue that in some ways Crocker was inspired to apply visual media to something other than the visible features of culture, such as 'technology' and "as an extension of a process of thought, a way for the filmmaker to explore a subject and for the viewer to follow that exploration" (MACDOUGALL, 2006, p. 241).

Perhaps, by engaging with 'the expressiveness of photography' (PINNEY, 1992, p. 67), I suggest that most of the anthropologist's effort has gone into putting the viewer into a particular relation to a Canela subject and creating a progression of images and scenes for understanding it, much as a musician produces a progression of notes and sequences. As a result of that, these series of photographs suggest a 'kinetic' (EDWARDS, 2001, p. 114), spatially embodied experience of Crocker's perspective - we can move our attention across the village amongst the Canela, photographically just as Crocker must have done physically.

\section{The embodied Amerindian community and its sociality: a Canela generous attitude}

The community is centered on a small village. Like many other communities in Brazil (IUVARO, 2012) this is a nucleated village. Crocker's visual documentation showed the structure of the Canela circular village of 'perhaps 90 houses of palm-thatch construction' (CROCKER, 1994). The Canela consisted of approximatively 400 people between the 1960s and 1970s'13 (GREENE and CROCKER, 1994). Crocker writes how in the earlier twentieth century it was extremely difficult to walk to even the closest urban center, which was more than five miles away (CROCKER, 1990). Isolated from other people by geography, it is not surprising to learn that they consider themselves to constitute a bounded community. The geography of "the village provides people with a convenient means of imaging inclusiveness" (JAMIESON, 2000, p. 83). At the same time, the community can be defined following Kidd and

\footnotetext{
${ }^{13}$ These data are based (according to Greene and Crocker 1994) on the 1970 census, the first ufficial one made among the group, as it was conducted for the Brazilian governement equivalent of the Census Bureau, the IBGE (see GREENE and CROCKER, 1994).
} 
Jamieson's insight (2000), as a well-defined moral universe.

The anthropologist's arrangement of images suggests that he clearly possesses a strong interest in the way photographs suggest the structure and sense of intimate space. Life in a Canela community allowed little privacy. The houses were situated in close proximity, sometimes at distances of just a few meters. There were very few possibilities for 'private' conversations. The photographs confirm to us that he was a sensitive and sympathetic field researcher and a keen observer of the shared nature of Canela existence: showing how they lived their life 'in the close company of others' (WALKER, 2013) and how effectively many individuals lived in each house ${ }^{14}$.

Figure 9. A series of photographs showing the Canela's houses situated in close proximity.

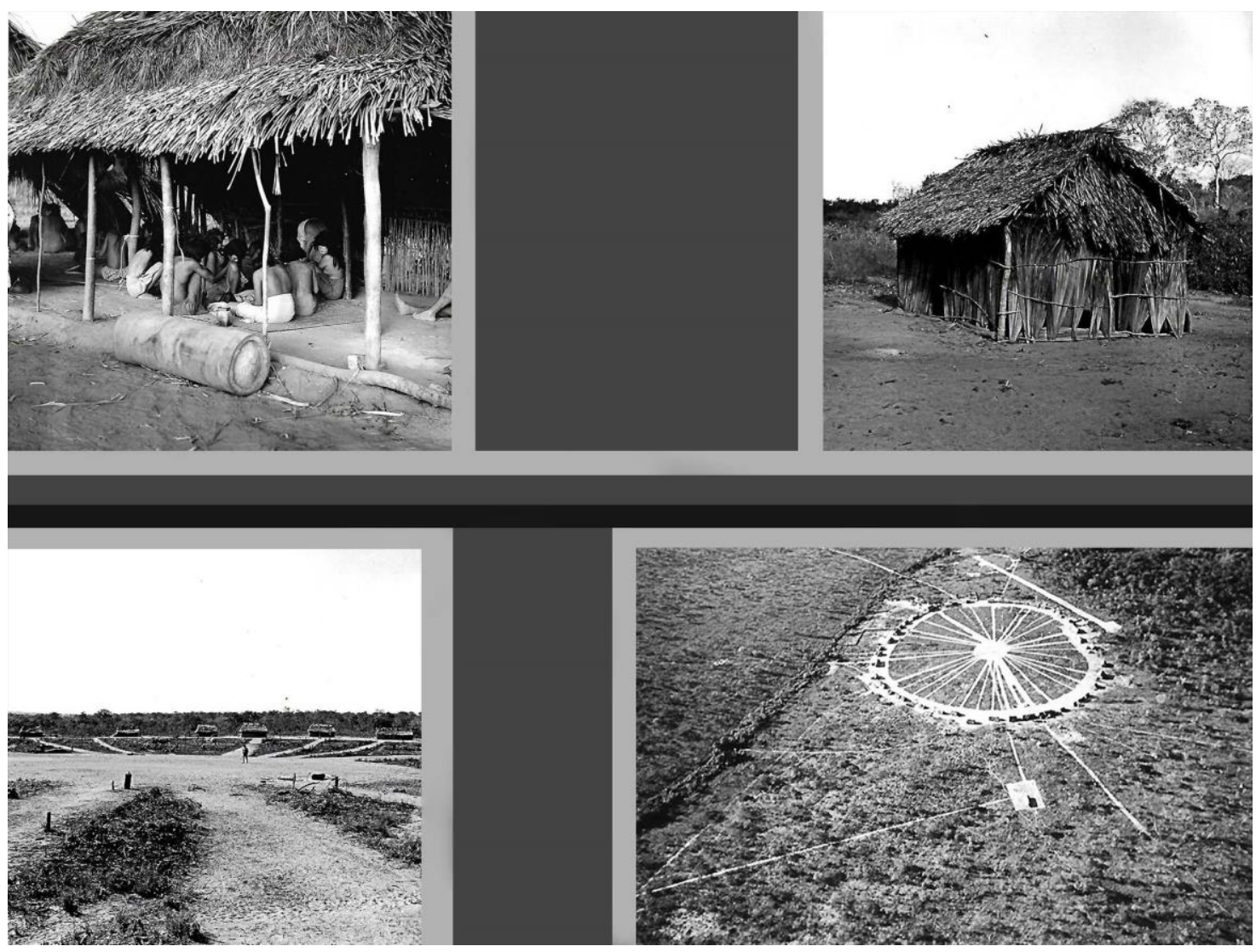

${ }^{14}$ Crocker in his monograph, The Eastern Timbira I: An Ethnographic Introduction (1990), takes particular care in describing how an individual Canela was a member of any one of a dozen kinship units that occupied houses around the village plaza. The Canela practiced a matrilocal residence pattern, "with women 'owning' the houses" (MILLER, 2016, p. 108). On marriage a man moved in with the house's wife but he retained important relationships with his natal kin group (for example with his sisters and sisters' sons). His loyalty was already divided between his natal household and the household of his spouse. Furthermore, he was tied strongly to specific individuals, such as Formal and Informal Friends. 
Figure 10. A series of photographs showing daily life activities including food preparation and distribution, preparing manioc and sharing meals.

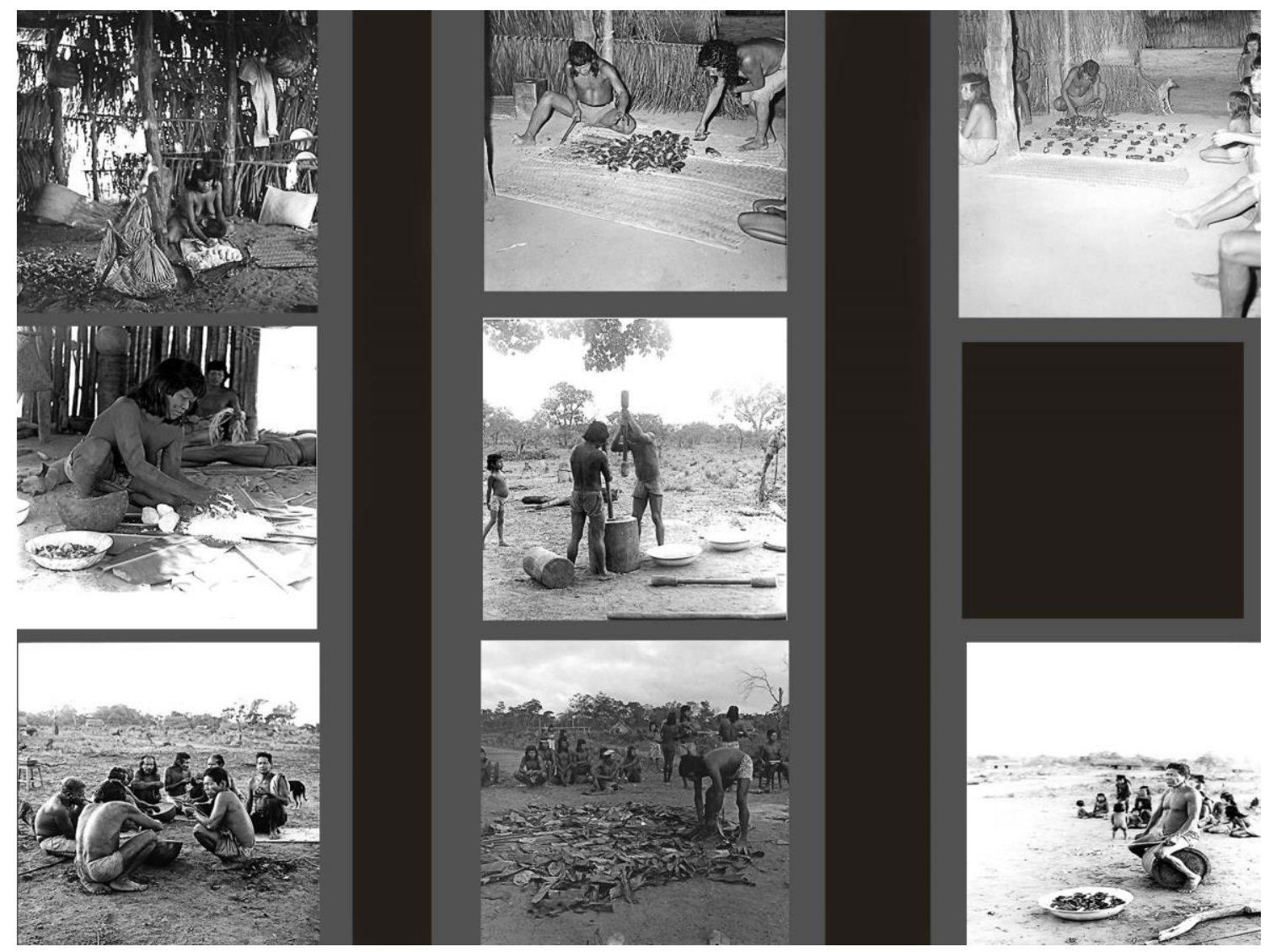

While in 'Western' folk concepts, we tend to think that 'private life' must be kept separate from (what is viewed as) the 'public sphere of interactions', communities such as the Canela, were a dense network of human relationships, and interactions among people were close and continuous ${ }^{15}$. Given this context, they are inevitably characterized by a high degree of personalization. A good example is to be found in many of Crocker's images which provide evidence of how they often brought gifts of food to each other at any time of the day; neighbors worked side-by-side; heavy daily work was done communally with the help of large sharing amounts of manioc beer and meat, and good humor (CROCKER, 1990) (Figures 9-10). One soon realizes that such community cohesion was not automatic, but actively "fostered by each

15 Canela society was described by Crocker as characterized by a plethora of 'cross-cutting associations' (WAGLEY, 1990, p. X) and formal relationships which assured maintenance of a village as a unit (NIMUENDAJÚ, 1946; CROCKER, 1990). Overall, Canela socialization may be seen as having encouraged relative dependency. 
person" (BELAUNDE, 2000, p. 213).

From the photographs, one can easily see how the Canela relied upon each other not only for the supply of food but also for other forms of trading and mutual services, such as raising children and corporate domestic work. A good example of this are the numerous images which depict their familial relationships, childcare activities, meetings with the chief and the sharing of domestic activities and meals (Figures 11-13).

The anthropologist was able to transmit to us a highly sentimentalized view of this. As suggested by Lotman (2000), "the spatial order depicted in photographs, for example, becomes an organizing element around which its non-spatial features are also constructed" (LOTMAN, 2000, p. 123). The community members were often photographed from a short distance, the camera in the midst of the action, providing a close-up of the events and what was going on. For example, the joy and playfulness of children's lives and family-child interactions were all vividly captured. (Figure 11).

From a close reading of Crocker's archive of images, "a multitude of close-ups shows the very instant in which the general is transformed into the particular" (MACDOUGALL, 2006, p. 57) and the quality of these photos is generally higher and engaged. This can be related to the fact that Crocker was mostly following an unfolding series of Canela activity, rather than recording short passages of unrelated events. The images were not made in accordance with a formal script, where Crocker directed the scene and instructed the Canela in what to do; it represented a complex narrative of Canela life unfolding systematically over a long period of time16. Crocker never missed an opportunity to depict the emotional links which tied the Canela one to another.

\footnotetext{
${ }^{16}$ Rather than being a series of isolated incidents held together loosely by an intermittent chronology. The material is not shot in a 'detached observation mode' remembering Mead's method (HENLEY, 2013, p. 96).
} 
Fabiola Iuvaro - William Crocker's photographic collection among the canela of central brazil

Figure 11. A series of photographs showing interactions of children and infants.

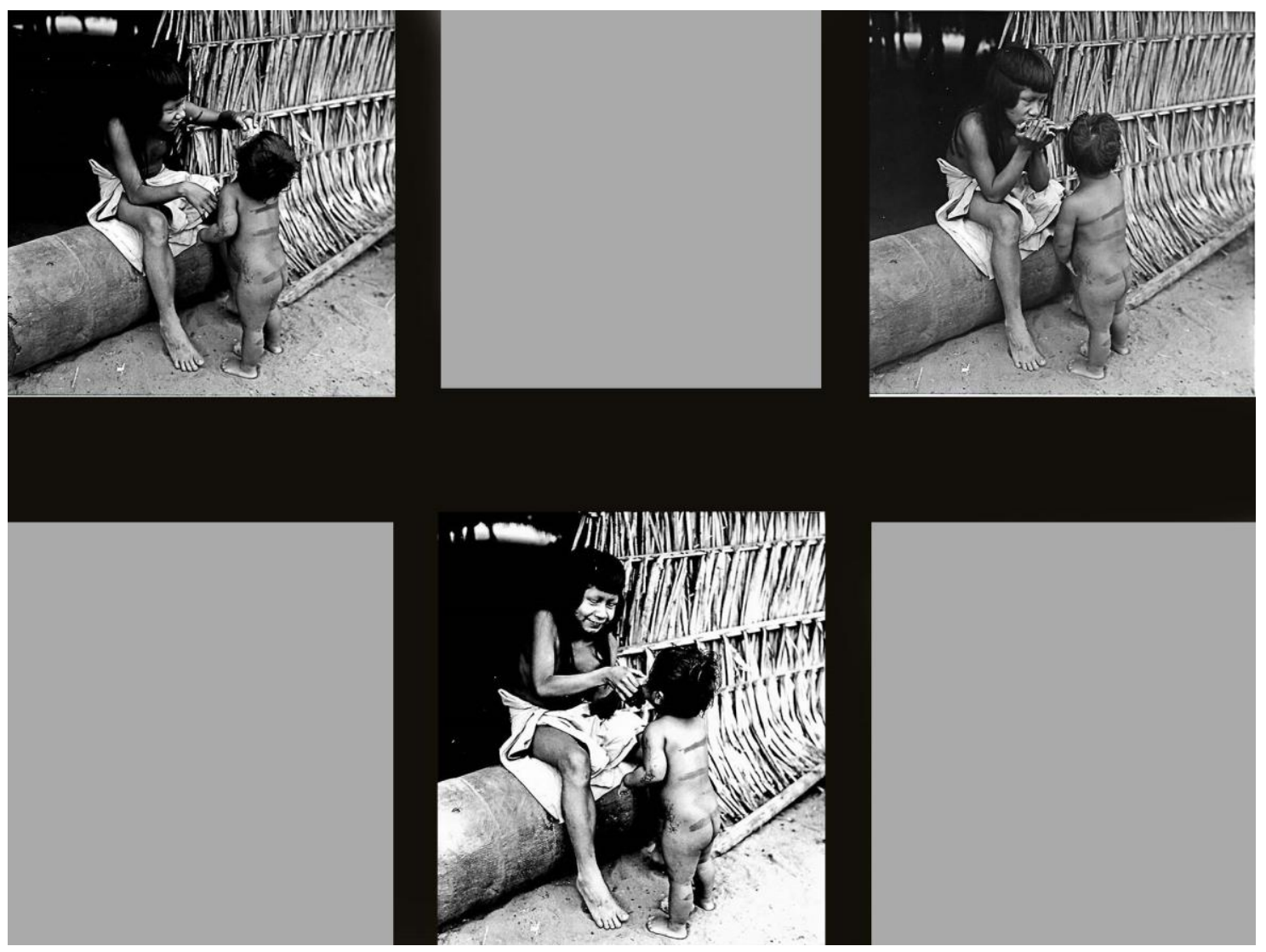

The intimacy continued, as the baby began to breast-feed in the figure (12) below. At some point the shots were extremely close, where the grandmother warmed her hands on his head and then attempted to keep the baby calm and safe (Figure 12). 
Fabiola Iuvaro - William Crocker's photographic collection among the canela of central brazil

Figure 12. A series of photographs showing interactions of parents, siblings and infants.
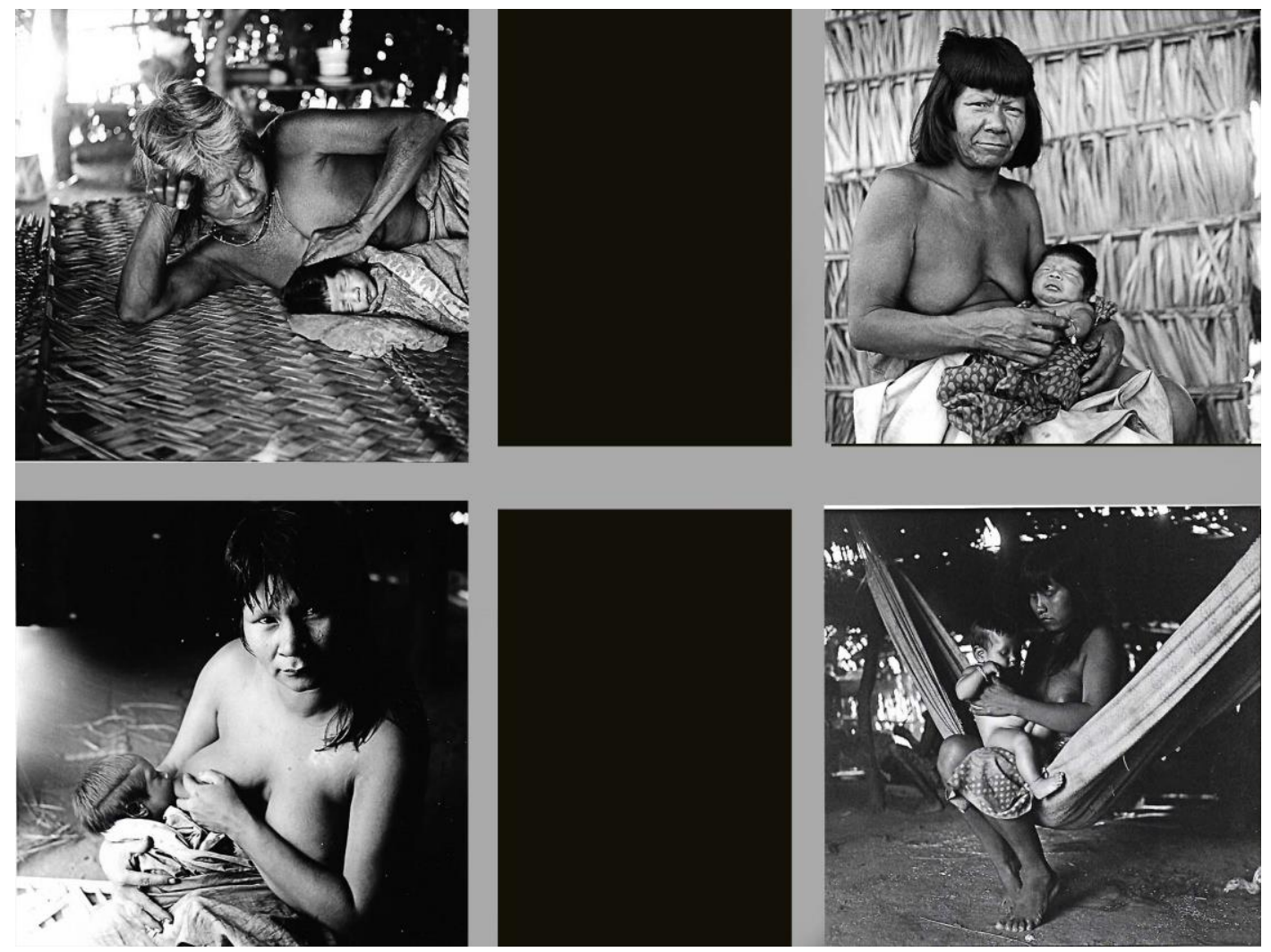

Figure 13. A series of photos showing Canela's portraits.

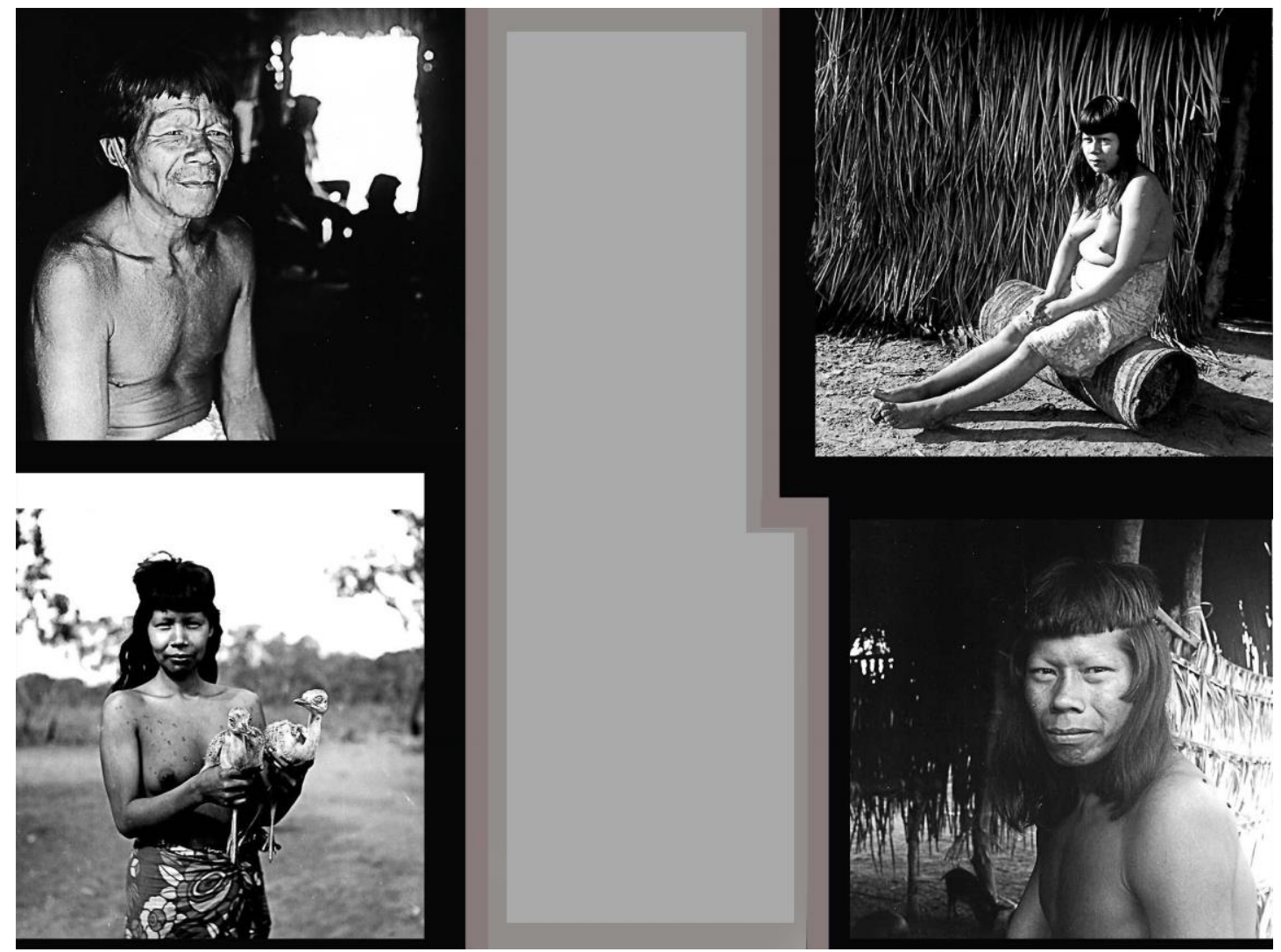

Espaço Ameríndio, Porto Alegre, v. 11, n. 1, p. 93-129, jan./jun. 2017. 
In recording Canela behavior, Crocker left us an archive of images of their inner world, their altruistic attitudes and social relationships. These photographs literally made visible Crocker's anthropological exploration of their social and belief systems. All these actions were marks of attention, affection; and as suggested by Alés (2000) among the Yanomami peoples, they are "constructive of everyday life, sociality and conviviality" (ALÉS, 2000, p. 136).

The social and the affective states (PASSES, 2000) - in which shared activities are depicted in Crocker's photographs - in a spirit of communality, amicability and merriment - evoke and correspond with the notion of 'conviviality' (KIDD, 2000; BELAUNDE, 2000; amongst others) and 'the moral economy of intimacy' (OVERING and PASSES, 2000; LONDÕNO-SULKIN, 2000; LAGROU, 2009). This is to say that Crocker's images explored in the literal and figurative sense a particular Canela conviviality, "a Canela way of being, typified by these selfsame attributes of friendship, generosity and pleasurable sociality" (PASSES, 2000, p. 99).

In summary, Crocker's collection enables us to explore the affective space of their personal relationships centered around their everyday care and responsibility of each other. Through a close analysis of them, we become aware of what made private life, economic cooperation, public events, run so smoothly in the community. In this way, I propose to read these images as - what Geismar (2006) called elsewhere - "visual histories" of a particular form of "Amerindian conviviality'.

\section{Conclusions}

Interestingly, in the 1950s, and indeed for at least two decades after that, the dominant tendency in academic anthropological research was to interpret any form of study of the everyday as banal or insignificant, even when they were entirely concerning of a particular and traditional meal preparation in a ceremonial context (OVERING and PASSES, 2000). Overing and Passes (2000) states how: "for the viewpoint of many anthropologists, shamans interactions with cannibal gods, 
warriors lopping off the heads and curare were much more exciting prospects than native people preparing communal meals or training and caring for children" (OVERING and PASSES, 2000, p. 9). And yet, interestingly, since the 1990s the approach to the moral economy of intimacy of the British School of Americanism, has recently posited how it is only by paying close attention to the details of Amerindian everyday life that anthropologists can begin to understand the strong 'native' belief systems, the norms and rules, in short what the forces of order in a native community consist of. The anthropologist's quest was to begin the "process of creating an 'anthropology of the everyday' where the moral virtues and the aesthetics of interpersonal relations, were the overriding concern" (OVERING and PASSES, 2000, p. 8). Consequently, this growing literature (e.g., BELAUNDE, 2000; KIDD, 2000; LAGROU, 2000; JAMIESON, 2000; WALKER, 2013; amongst others) posit how the everyday was not banal or insignificant, on the contrary it was essential in order to engage with Amerindian views of sociality.

From drawing on Crocker's methodological field use of 'mimetic technologies of photography' (EDWARDS, 2001), to depict the Canela way of life, I was able to conclude that his work in the mid 1950s was a precursor to paying attention to the 'everyday affective side' of an Amerindian sociality. Certainly, Crocker's ethnography is not the only one to achieve a comprehensive understanding of the "affective side of an Amerindian group", however, it can be considered one of the most visually documented ones for Lowland South America.

Ironically, Edwards (2001) challenged our understanding of photographs when she said that "we may feel photography and film can never inform us in a relevant way because we are dealing with such a different level of history" (EDWARDS, 2001, p. 102). I believe the opposite of the above quotation, namely "images can definitely inform us" (EDWARDS, 2001, p. 102), in particular, with reference to Crocker's images, I can say they inform us not only about the 'minutiae of Canela ordinary life'. But the images explore also the themes of generosity, compassion and I would say love. These are stories and theories of Canela ideas about how to live well, and are some of the most interesting pieces of their historical documentation. Crocker was not a historian attempting to reform the memory of the group through 
archival evidence, although his archival documentation should pique the interest of anyone in the field.

Learning and sharing theories of where we come from is as much a part of our journey as a species as the one our bodies undergo. Recently, one of Crocker's newest research assistants wrote to him: "I am Carampei. I wonder if we Canela will maintain our identity" (CARAMPEI quoted in CROCKER, 1994, p. 132). Carampei's message is part of an important project developed by Crocker since the 1960s, namely his use of Canela research assistants to write and later speak their current life stories, in the form of diaries. According to the anthropologist these run up to 2014. In effect, Carampei's fear of loosing his identity reflects the ambiguity of his position among the Brazilians these days; the economic deprivation of the Canela, their social isolation, and the 'lingering prejudices of the Brazilians', which were all condensed in Carampei's awareness. Was he afraid to announce himself as a Canela? Or was he proud to be confused with the whites.

The rich archive of Crocker's older images can reassure Carampei today. These historical photographs become a kind of 'memory bookend' (HARPER, 2002) that represents the Canela subjectivity, embodied in their framing. They form a starting point from which the Canela could see themselves in images from earlier decades of their life which they had not specifically imagined for decades. In Crocker's photos, for example, Carampei was depicted as a little boy joking with his brother and chopping a banana tree with a machete and holding holding back a blow to avoid hurting his sister. He appears later, in 1997 , as a young father taking care of his children. Now aged 27 , he is studying to become a professional, to work in his community and provide a better future for his children. Carampei's photos show how the Canela were able to move in the mainstream Brazilian world and have learned many of its ways (CROCKER, 1994).

Today Crocker's archival documentation enterprise comes to have even more historical and valuable weight. Brazil is currently undergoing a period of intense political turbulence, largely at the expense of Indians' rights and their visibility.

Crocker's images prove to be the important link between the Canela's ordinary experience of their lives through their collective 
stories (namely sharing practices and services), through to personal historical moments of a Canela individual like Carampei, invoking a complex system of different relationships, in turn defining the moral principles of the Canela community.

This 'photographic ethnography' can be considered an important aspect of their collective past, and portraits that evoke the era in which their identity was inscribed in the facial expressions, the gestures, and the 'interactional mannerisms of the people photographed' (HARPER, 2002 , p. 19). They evoke deep reflections on particular key Canela values and modes of conduct, including their relationship within the group and their identity as Canela. The images direct our attention to an existential human predicament: namely, the importance of our memories.

All photographs presented in the article belong to Crocker's collections stored at the Department of Anthropology, Natural History Museum, Smithsonian Institution, Washington, D.C.

\section{Bibliography}

BATESON, Gregory; MEAD, Margaret. Balinese Character: a photographic Analysis. New York Academy of Sciences, Special Publications 2, 1942. 160-177, 1951.

In Bali: the use of photography and film. Cultural Anthropology, v. 3, n. 2, p.

BELAUNDE, Luisa Elvira. Parrots and oropendolas: the aesthetics of gender relations among the Airo-Pai of the Peruvian Amazon. Journal de la Societee des Americanistes, v. 80, p. 95-111, 2000.

BERLEANT, Arnold. Introduction: art, environment, and the shaping of experience. In: Environment and the arts: perspectives on environmental aesthetics. Aldershot: Ashgate Press, 2002, p. 1-23.

BELTING, Hans. An anthropology of images. Picture. Medium. Body. Munich: Verlag Wilhelm Fink, 2011.

CLIFFORD, James. Person and myth: Maurice Leenhardt in the Melanesian world. 
Durham: Duke University Press, 1989.

COLLIER, John; COLLIER, Malcom. Visual Anthropology: Photography as a Research Method. Mexico: University of New Mexico Press, 1967.

CROCKER, William. Canela Initiation Festivals: 'Helping Hands' through Life. Washington: Smithsonian Institution Press, 1982.

The Canela (Eastern Timbira): An ethnographic introduction: Smithsonian contributions to anthropology. Washington: Smithsonian Institution Press, 1990.

Canela. Relationships with Ghosts: This Worldly or Otherworldly Empowerment. Latin American Anthropology Review, v. 5, n. 2, p. 71-78, 1993.

Encyclopedia of World Cultures. Boston: G. K. Hall \& C, 1994.

The Canela Diaries: Their Nature, Uses and Future. Tipití: Journal of the Society for the Anthropology of Lowland South America, v. 5, p. 33-55, 2007.

CROCKER, William; CROCKER, Jean. The Canela: bonding through kinship, ritual, and sex. In: HOLT, Rinehart; WINSTON, Orlando (Org.). Case studies in cultural anthropology. Florida: Smithsonian Institution, 1994.

CROCKER, Margaret E. Greene; CROCKER, William. Some Demographic Aspects of the Canela Indians of Brazil. In: BENNINGTON COLLEGE. South American Indian Studies. Kathleen Adams and David Price Press, 1994. p. 47-62.

EDWARDS, Elizabeth. Material beings: objecthood and ethnographic photographs. Visual Studies, v. 17, n. 1, p. 67-75, 2001.

FLOWERS, Nancy. Subsistence Strategy, Social Organization and Welfare in Central Brazil in the context of the European penetration. In: ROOSEVELT, A. Amazonian Indians from Prehistory to the Present: Anthropological perspectives. Tucson: Arizona University Press, 1994. P. 249-275.

FORTES, Meyer. Social Structure. London: Routledge, 1973.

FOSTER, Hal. An archival impulse. MIT Press Journals, Cambridge, Massm v. 1, p. 3-22, 2004.

GEISMAR, Haidy Malakula. A photographic collection. Society for Comparative Study of Society and History. 2006. p. 521-562.

GELL, Alfred. Art and Agency: An anthropological theory. Oxford: Clarendon Press, 1998.

GOFFMAN, Erving. Interaction Ritual: essays on face-to face Behavior.. In: MACDOUGALL (Org.). The corporeal image. New York: Doubleday/Anchor, 1967. 
. Cubeo Hehenewa Religious Thought: Metaphysics of a Northwestern Amazonian People. New York: Routledge, 1975.

HENLEY, Paul. From documentation to Representation: Recovering the Films of Margaret Mead and Gregory Bateson. Visual Anthropology, v. 26, p. 75-108, 2013.

HOCKINGS, Paul. Principle of Visual Anthropology. The Hague and Paris: Mounton Publisher, 1988.

INGOLD, Tim. Materials against materiality. Archaeological Dialogues, v. 14, n. 1, p. 1-16, 2007.

IUVARO, Fabiola. A criatividade artística kadiwéu: entrevista com Benilda Vergílio. Espaço Ameríndio, Porto Alegre, v. 6, , n. 2, p. 69-96, 2012.

O papel das Instituições Informais no Desenvolvimento de Projetos de geração de renda em comunidades indígenas em Mato Grosso do Sul, CentralBrazil (Solidarity Norms and Informal Institutions in Central Brazilian indigenous communities: Participatory development project). Campo Grande: Universidade Católica Dom Bosco, 2014.

JACKNIS, Ira. Margaret Mead and Gregory Bateson in Bali: Their Use of Photography and Film. Cultural Anthropology, v. 3, n. 2, p. 160-177, 1988.

JAMIESON, Mark. Compassion, anger and broken hearts: ontology and the role of language in the Miskitu lament. In: OVERING, J.; PASSES, A. (Org.). The anthropology of love and anger: the aesthetics of conviviality in native Amazonia. London: Routledge, 2000a. p. 82-96.

It's shame that makes men and women enemies: the politics of intimacy among the Miskitu of Kakabila. RJAI, Royal Anthropological Institute, v. 6, n. 2. 2000b.

KIDD, Stephen W. Knowledge and the practice of love and hate among the Enxet of Paraguay. In: OVERING, J.; PASSES, A. (Org.). The anthropology of love and anger: the aesthetics of conviviality in native Amazonia. London: Routledge, 2000. p. 113-131.

LAGROU, Els. Homesickness and the Cashinahua self. A reflection on the embodied condition of relatedness. In: OVERING, J.; PASSES, A. (Org.). The anthropology of love and anger: the aesthetics of conviviality in native Amazonia. London: Routledge, 2000. p. 153-169.

The crystallized Memory of Artifacts. A reflection on Agency in Cashinahua Image-Making. In: SANTOS-GRANERO, F. (Org.). The Occult life of Things. Arizona: University of Arizona Press, 2009.

LONDÕNO-SULKIN, Carlos David. Thought comes as evil, I embrace it as good': 
social sensibilities and the transformation of malignant agency among the Muinane. In: OVERING, J.; PASSES, A. (Org.). The anthropology of love and anger: the aesthetics of conviviality in native Amazonia. London: Routledge, 2000. p. 133-152.

Inhuman beings: mortality and perspectivism among Muinane people (Colombian Amazon). Ethnos, v. 70, n. 1, p. 7-30, 2005.

LOTMAN, Juri. Culture and explosion: Semiotics, Communication and Cognition. New York: Mouton de Gryter, 2000.

MACDOUGALL, David. The corporeal image: Film, ethnography, and the sense. New Jersey: Princeton University Press, 2006.

MAYBURY-LEWIS, David. The Savage and the Innocent. Dundee: Jenhams Books, 1965.

MILLER, L. Theresa. Maize as material culture? Amazonian theories of persons and things. Journal of the Anthropological Society of Oxford, v. 3, n. 1, p. 67-89, 2012.

NIMUENDAJÚ, Curt. The Eastern Timbira. Los Angeles: University of California Press, 1946.

OVERING, Joanna K. Review article: The Amazonian anthropology. Journal of Latin American Studies, v. 13, n. 1, 1999.

OVERING, J.; PASSES, A. (Org.). The anthropology of love and anger: the aesthetics of conviviality in native Amazonia. London: Routledge, 2000.

PINNEY, Christopher. The Parallel Histories of Anthropology and Photography. In: EDWARDS, E. (Org.). Anthropology and Photography: 1860 - 1920. New Haven: Yale University Press, and London: The Royal Anthropological Institute, 1992.

SPLINDER, George and Luise. Foreword: About William Crocker's work. In: CROCKER, William; CROCKER, Jean (Org.). The Canela Bonding through kinship, ritual, and sex: Cases studies in cultural anthropology. Series Editors: George and Louise Spindler. Holt: Rinehart and Winston Press, 1994. p. vii-ix.

STEWARD, Julian H. Handbook of South American Indians. Bulletin (Smithsonian Institution. Bureau of American Ethnology). Washington D.C.: Govt. Printing Office, 1946-1959.

WAGLEY, Charles. Introduction. In: CROCKER, William. The Canela (eastern Timbira), I. Washington: Smithsonian Institution Press,. 1990.

WALKER, Harry. Baby Hammocks and stone Bowls: Urarina Technologies of Companionship and Subjection. In: SANTOS-GRANERO, F. (Org.). The Occult life of Things. Arizona: University of Arizona Press, 2009, p. 81-102. 
Fabiola Iuvaro - William Crocker's photographic collection among the canela of central brazil

WALKER, Harry. Under a watchful eye: self, power and intimacy in Amazonia. Los Angeles, California: University of California Press, 2013.

Recebido em: 02/04/2017 * Aprovado em: 21/06/2017 * Publicado em: 30/06/2017 